Article

\title{
Bioactive Phenolic and Isocoumarin Glycosides from the Stems of Homalium paniculiflorum
}

\author{
Shou-Yuan Wu ${ }^{1,+}$, Yan-Hui Fu ${ }^{1,+}$, Qi Zhou ${ }^{1}$, Meng Bai ${ }^{1}$, Guang-Ying Chen ${ }^{1}$, Si-Yu Zhao ${ }^{1}$, \\ Chang-Ri Han ${ }^{2, *}$ and Xiao-Ping Song $1, *(10)$ \\ 1 Key Laboratory of Tropical Medicinal Plant Chemistry of Ministry of Education, Hainan Normal University, \\ Haikou 571158, China; wushouyuan2012@163.com (S.-Y.W.); fuyanhui80@163.com (Y.-H.F.); \\ zhouqi0313@163.com (Q.Z.); XXbai2014@163.com (M.B.); chgying123@163.com (G.-Y.C.); \\ 13876740482@163.com (S.-Y.Z.) \\ 2 Key Laboratory of Medicinal and Edible Plants Resources of Hainan Province, Hainan Institute of Science \\ and Technology, HaiKou 571126, China \\ * Correspondence: hchr116@126.com (C.-R.H.); sxp628@126.com (X.-P.S.); Tel./Fax: +86-898-65889422 (X.-P.-S.) \\ + These authors contributed equally to this work.
}

Received: 2 January 2018; Accepted: 11 February 2018; Published: 22 February 2018

\begin{abstract}
Two new phenolic glycosides (1 and 2 ) and two new isocoumarin glycosides ( 3 and $\mathbf{4})$, along with 14 known compounds (5-18), were isolated from the stems of Homalium paniculiflorum. Their structures were established on the basis of extensive spectroscopic analyses and chemical methods. All new compounds were evaluated for their anti-inflammatory activities via examining the inhibitory activity on nitric oxide (NO) production induced by lipopolysaccharide (LPS) in mouse macrophage RAW 264.7 cells in vitro. Compounds 1 and 4 exhibited inhibitory activities with $\mathrm{IC}_{50}$ values of $30.23 \pm 1.23 \mu \mathrm{M}$ and $19.36 \pm 0.19 \mu \mathrm{M}$, respectively.
\end{abstract}

Keywords: Homalium paniculiflorum; phenolic glycosides; isocoumarin glycosides; NO production inhibition

\section{Introduction}

The genus Homalium (Flacourtiaceae), comprising about 130 species, are mainly distributed in temperate and subtropical regions. There are about 12 species of this genus in China, growing from the southwest to Taiwan. Among which, H. paniculiflorum is a Chinese endemic plant, only distributed in China's Hainan Island [1]. Previous phytochemical investigations on the genus have afforded various types of compounds including phenolic glycosides, xanthenes, iridoids, coumarins, triterpenoids and alkaloids, which showed a wide variety of interesting bioactivities including anti-bacterial, anti-oxidant, anti-viral, anti-plasmodial, hypolipidemic and hypoglycemic activities [2-11]. As a Chinese endemic medicinal plant, up to now, there is only a preliminary investigation on the chemical composition of H. paniculiflorum performed by us recently $[10,11]$. As a part of our ongoing research into structurally and biologically interesting natural products from tropical medicinal plants in China, a further chemical investigation on H. paniculiflorum was undertaken and had led to the isolation of two new phenolic glycosides and two new isocoumarin glycosides (1-4) (Figure 1), along with 14 known compounds, vanillin (5) [12], 2,4-dihydroxybenzaldehyde (6) [13], 4-hydroxy-3,5-dimethoxybenzaldehyde (7) [14], $\beta$-hydroxypropiovanillone (8) [15], coniferaldehyde (9) [16], 2-hydroxy phenyl- $\beta$-glucoside (10) [17], helicin (11) [18], salirepin (12) [4], salireposide (13) [3], homaloside B (14) [3], poliothrysoside (15) [19], itoside H (16) [20], 3-phenylisocoumarin (17) [7] and 3-(3'-hydroxyphenyl) isocoumarin (18) [8]. The structures of the new compounds 1-4 were elucidated by extensive spectroscopic analyses and chemical methods, while the known compounds were identified by comparisons their data with those reported in the literature. In addition, all new compounds were evaluated for their anti-inflammatory 
activities via examining the inhibitory activity on NO production induced by LPS in mouse macrophage RAW 264.7 cells in vitro. Compounds 1 and 4 exhibited inhibitory effects with $\mathrm{IC}_{50}$ values comparable to that of L-NMMA (NG-Methyl-L-arginine). Herein, we describe the isolation, structural elucidation and anti-inflammatory activities of these new compounds.

\section{Results and Discussion}

The methanol extract of the stems of H. paniculiflorum was suspended in water and extracted successively with petroleum ether and EtOAc. The EtOAc extract was repeatedly subjected to silica gel CC, reversed-phase $C_{18}$ silica gel CC, Sephadex LH-20 CC and semi-preparative HPLC, to yield 18 compounds, including two new phenolic glycosides ( $\mathbf{1}$ and $\mathbf{2})$ and two new isocoumarin glycosides (3 and 4), as shown in Figure 1.<smiles>O=C(OC[C@H]1O[C@@H](Oc2ccc(O)cc2O)[C@H](O)[C@@H](O)[C@H]1O)c1ccc(F)cc1</smiles>

1<smiles>O=C1O[C@H](c2ccc(O)c(O[C]3O[C@H](CO)[C@@H](O)[C@H](O)[C@H]3O)c2)[C@H]2C=C[C@H]1C2</smiles>

3<smiles>O=Cc1ccccc1O[C@H]1O[C@H](COC(=O)/C=C/c2ccc(O)cc2)[C@@H](O)[C@H](O)[C@H]1O</smiles>

2<smiles>O=C1O[C@@H](c2ccc(O)c(O[C@@H]3O[C@H](CO)[C@@H](O)[C@H](O)[C@H]3O)c2)Cc2ccccc21</smiles>

4

Figure 1. Chemical structures of compounds 1-4.

Compound 1 was obtained as a white amorphous powder. Its molecular formula was determined as $\mathrm{C}_{27} \mathrm{H}_{26} \mathrm{O}_{10}$ by HRESIMS ( $m / z 533.1413[\mathrm{M}+\mathrm{Na}]^{+}$, calcd. 533.1418), indicating 15 degrees of unsaturation. Its IR spectrum showed the presence of hydroxyl groups $\left(3468 \mathrm{~cm}^{-1}\right)$, an ester carbonyl group (1708 and $1676 \mathrm{~cm}^{-1}$ ) and phenyl groups $\left(1620,1518\right.$ and $\left.1493 \mathrm{~cm}^{-1}\right)$. The UV maxima at 262 and $218 \mathrm{~nm}$ indicated that 1 possessed aromatic rings. The ${ }^{13} \mathrm{C}-\mathrm{NMR}$ and DEPT data (Table 1 ) revealed the presence of 27 carbon atoms, including $20 \mathrm{sp}^{2}$ carbon atoms, five $\mathrm{sp}^{3}$ methines and two $\mathrm{sp}^{3}$ methylenes, which were attributable to two benzoate groups, one benzyl alcohol group and one glucopyranosyl moiety. The above data revealed that the structure of 1 was similar to that of itoside H (16) [20], except that the hydroxyl group at $\mathrm{C}-2^{\prime}$ was substituted by a hydrogen atom, which was supported by the HMBC correlations of $\mathrm{H}-2^{\prime}$ to $\mathrm{C}-4^{\prime}\left(\delta_{\mathrm{C}} 134.2\right), \mathrm{C}-6^{\prime}\left(\delta_{\mathrm{C}} 130.6\right)$ and $\mathrm{C}-7^{\prime}\left(\delta_{\mathrm{C}} 167.8\right)$, as well as the ${ }^{1} \mathrm{H}-{ }^{1} \mathrm{H}$ COSY correlations from $\mathrm{H}-2^{\prime}$ to $\mathrm{H}-6{ }^{\prime}$. Detailed analysis of 2D-NMR (HSQC, HMBC and ${ }^{1} \mathrm{H}-{ }^{1} \mathrm{H}$ COSY) spectra confirmed the structure of $\mathbf{1}$ (see Figure 2). Furthermore, the coupling constant of the anomeric proton resonating at $\delta_{\mathrm{H}} 4.79\left(1 \mathrm{H}, \mathrm{d}, J=7.6 \mathrm{~Hz}, \mathrm{H}-1^{\prime \prime}\right)$ suggested that the glucopyranosyl moiety was $\beta$-glucoside. In order to further confirm the structure of $\mathbf{1}$, the acid hydrolysis reaction of 1 was carried out. As a result, a $\beta$-D-glucose was produced as the sole sugar identified on the basis of the same $R_{f}$ value on co-TLC and the almost identical optical value by comparing with that of an authentic sugar sample. Therefore, compound 1 was determined as 4-hydroxy-2-\{[(benzoyl)oxy] methyl\}phenyl- $\beta$-D-glucopyranoside-6-benzoate, as shown in Figure 1. 


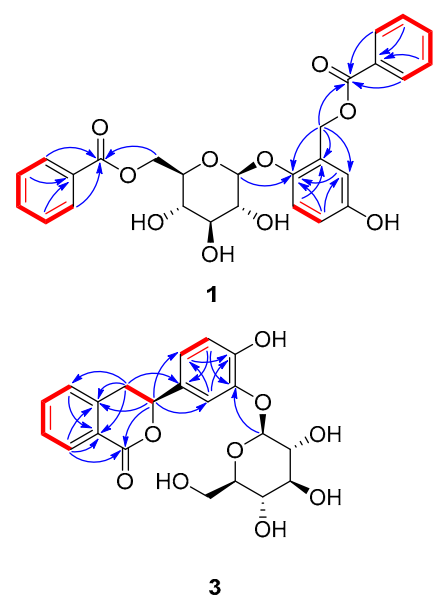

- ${ }^{1} \mathrm{H}-{ }^{1} \mathrm{H} \cos Y$

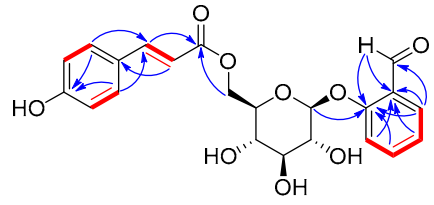

2

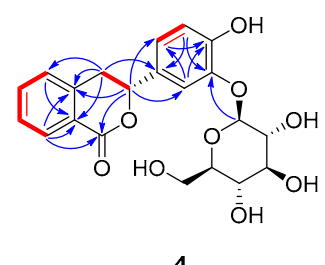

4

НMBC

Figure 2. Key $\mathrm{HMBC}$ and ${ }^{1} \mathrm{H}-{ }^{1} \mathrm{H}$ COSY correlations for compounds $\mathbf{1 - 4}$.

Table 1. ${ }^{1} \mathrm{H}$ and ${ }^{13} \mathrm{C}$-NMR data of compounds 1 and 2 in $\mathrm{CD}_{3} \mathrm{OD}$.

\begin{tabular}{|c|c|c|c|c|}
\hline \multirow{2}{*}{ Position } & \multicolumn{2}{|c|}{ Compound 1} & \multicolumn{2}{|c|}{ Compound 2} \\
\hline & $\delta_{\mathbf{H}^{\mathrm{a}}}$ & $\delta_{\mathrm{C}}^{\mathbf{b}}$ & $\delta_{\mathbf{H}^{\mathrm{a}}}$ & $\delta_{\mathrm{C}}^{\mathbf{b}}$ \\
\hline 1 & & $129.4 \mathrm{~s}$ & & $127.5 \mathrm{~s}$ \\
\hline 2 & & $149.7 \mathrm{~s}$ & & $161.3 \mathrm{~s}$ \\
\hline 3 & $7.07(1 \mathrm{H}, \mathrm{d}, 8.0)$ & $119.9 \mathrm{~d}$ & $7.31(1 \mathrm{H}, \mathrm{d}, 7.6)$ & $118.2 \mathrm{~d}$ \\
\hline 4 & $6.55(1 \mathrm{H}, \mathrm{dd}, 8.0,2.0)$ & $116.4 \mathrm{~d}$ & $7.50(1 \mathrm{H}, \mathrm{dd}, 7.6,7.6)$ & $137.1 \mathrm{~d}$ \\
\hline 5 & & $154.3 \mathrm{~s}$ & $7.08(1 \mathrm{H}, \mathrm{dd}, 7.6,7.6)$ & $123.8 \mathrm{~d}$ \\
\hline 6 & $6.83(1 \mathrm{H}, \mathrm{d}, 2.0)$ & $116.2 \mathrm{~d}$ & $7.76(1 \mathrm{H}, \mathrm{d}, 7.6)$ & $128.7 \mathrm{~d}$ \\
\hline $7 \alpha$ & $5.46(1 \mathrm{H}, \mathrm{d}, 13.2)$ & $63.1 \mathrm{t}$ & $10.50(1 \mathrm{H}, \mathrm{s})$ & $191.8 \mathrm{~d}$ \\
\hline $7 \beta$ & $5.41(1 \mathrm{H}, \mathrm{d}, 13.2)$ & & & \\
\hline $1^{\prime}$ & & $131.3 \mathrm{~s}$ & & $127.1 \mathrm{~s}$ \\
\hline $2^{\prime}$ & $7.98(1 \mathrm{H}, \mathrm{d}, 7.6)$ & $130.6 \mathrm{~d}$ & $7.46(1 \mathrm{H}, \mathrm{d}, 8.4)$ & $131.2 \mathrm{~d}$ \\
\hline $3^{\prime}$ & $7.45(1 \mathrm{H}, \mathrm{dd}, 7.6,7.6)$ & $129.6 \mathrm{~d}$ & $6.82(1 \mathrm{H}, \mathrm{d}, 8.4)$ & $116.9 \mathrm{~d}$ \\
\hline $4^{\prime}$ & $7.59(1 \mathrm{H}, \mathrm{dd}, 7.6,7.6)$ & $134.2 \mathrm{~d}$ & & $161.5 \mathrm{~s}$ \\
\hline $5^{\prime}$ & $7.45(1 \mathrm{H}, \mathrm{dd}, 7.6,7.6)$ & $129.6 \mathrm{~d}$ & $6.82(1 \mathrm{H}, \mathrm{d}, 8.4)$ & $116.9 \mathrm{~d}$ \\
\hline $6^{\prime}$ & $7.98(1 \mathrm{H}, \mathrm{d}, 7.6)$ & $130.6 \mathrm{~d}$ & $7.46(1 \mathrm{H}, \mathrm{d}, 8.4)$ & $131.2 \mathrm{~d}$ \\
\hline $7^{\prime}$ & & $167.8 \mathrm{~s}$ & $7.61(1 \mathrm{H}, \mathrm{d}, 16.0)$ & $146.8 \mathrm{~d}$ \\
\hline $8^{\prime}$ & & & $6.33(1 \mathrm{H}, \mathrm{d}, 16.0)$ & $114.9 \mathrm{~d}$ \\
\hline $9^{\prime \prime}$ & & & & $168.9 \mathrm{~s}$ \\
\hline $1^{\prime \prime}$ & $4.79(1 \mathrm{H}, \mathrm{d}, 7.6)$ & $104.7 \mathrm{~d}$ & $5.05(1 \mathrm{H}, \mathrm{d}, 7.6)$ & $102.7 \mathrm{~d}$ \\
\hline $2^{\prime \prime}$ & $3.53-3.49(1 \mathrm{H}, \mathrm{m})$ & $75.0 \mathrm{~d}$ & $3.61-3.57(1 \mathrm{H}, \mathrm{m})$ & $74.8 \mathrm{~d}$ \\
\hline $3^{\prime \prime}$ & $3.49-3.46(1 \mathrm{H}, \mathrm{m})$ & $78.0 \mathrm{~d}$ & $3.55-3.50(1 \mathrm{H}, \mathrm{m})$ & $77.9 \mathrm{~d}$ \\
\hline $4^{\prime \prime}$ & $3.45-3.40(1 \mathrm{H}, \mathrm{m})$ & $72.1 \mathrm{~d}$ & $3.47-3.43(1 \mathrm{H}, \mathrm{m})$ & $71.7 \mathrm{~d}$ \\
\hline $5^{\prime \prime}$ & $3.71-3.67(1 \mathrm{H}, \mathrm{m})$ & $75.5 \mathrm{~d}$ & $3.78-3.74(1 \mathrm{H}, \mathrm{m})$ & $75.8 \mathrm{~d}$ \\
\hline $6^{\prime \prime} \alpha$ & $4.69(1 \mathrm{H}, \mathrm{dd}, 11.6,1.6)$ & $65.3 \mathrm{t}$ & $4.53(1 \mathrm{H}, \mathrm{dd}, 11.6,1.6)$ & $64.5 \mathrm{t}$ \\
\hline $6^{\prime \prime} \beta$ & $4.40(1 \mathrm{H}, \mathrm{dd}, 11.6,7.6)$ & & $4.39(1 \mathrm{H}, \mathrm{dd}, 11.6,6.8)$ & \\
\hline $1^{\prime \prime \prime}$ & & $131.5 \mathrm{~s}$ & & \\
\hline $2^{\prime \prime \prime}$ & $8.02(1 \mathrm{H}, \mathrm{d}, 7.6)$ & $130.6 \mathrm{~d}$ & & \\
\hline $3^{\prime \prime \prime}$ & $7.48(1 \mathrm{H}, \mathrm{dd}, 7.6,7.6)$ & $129.6 \mathrm{~d}$ & & \\
\hline $4^{\prime \prime \prime}$ & $7.61(1 \mathrm{H}, \mathrm{dd}, 7.6,7.6)$ & $134.3 \mathrm{~d}$ & & \\
\hline $5^{\prime \prime \prime}$ & $7.48(1 \mathrm{H}, \mathrm{dd}, 7.6,7.6)$ & $129.6 \mathrm{~d}$ & & \\
\hline $6^{\prime \prime \prime}$ & $8.02(1 \mathrm{H}, \mathrm{d}, 7.6)$ & $130.6 \mathrm{~d}$ & & \\
\hline $7^{\prime \prime \prime}$ & & $168.0 \mathrm{~s}$ & & \\
\hline
\end{tabular}

${ }^{\mathrm{a}}$ Measured at $400 \mathrm{MHz} ;{ }^{\mathrm{b}}$ Measured at $100 \mathrm{MHz}$. 
Compound 2 was obtained as a white amorphous powder. Its molecular formula was determined as $\mathrm{C}_{22} \mathrm{H}_{22} \mathrm{O}_{9}$ by HRESIMS with $m / z 453.1163[\mathrm{M}+\mathrm{Na}]^{+}$(calcd. for $\mathrm{C}_{22} \mathrm{H}_{22} \mathrm{O}_{9} \mathrm{Na}, 453.1162$ ), indicating 12 degrees of unsaturation. The IR spectrum showed the presence of hydroxyl group $\left(3442 \mathrm{~cm}^{-1}\right)$, carbonyl groups (1720 and $\left.1675 \mathrm{~cm}^{-1}\right)$ and phenyl groups $\left(1612,1516\right.$ and $\left.1468 \mathrm{~cm}^{-1}\right)$ functionalities. In the ${ }^{1} \mathrm{H}-\mathrm{NMR}$ spectrum of 2 (see Figure S6 in Supplementary Material), two groups of mutual coupled deshielded protons at $\delta_{\mathrm{H}} 7.31(1 \mathrm{H}, \mathrm{d}, J=7.6 \mathrm{~Hz}, \mathrm{H}-3), 7.50(1 \mathrm{H}, \mathrm{dd}, J=7.6,7.6 \mathrm{~Hz}, \mathrm{H}-4), 7.08$ $(1 \mathrm{H}, \mathrm{dd}, J=7.6,7.6 \mathrm{~Hz}, \mathrm{H}-5)$ and $7.76(1 \mathrm{H}, \mathrm{d}, J=7.6 \mathrm{~Hz}, \mathrm{H}-6)$, as well as $7.46\left(2 \mathrm{H}, \mathrm{d}, J=8.4 \mathrm{~Hz}, \mathrm{H}-2^{\prime}\right.$, $\left.\mathrm{H}-6^{\prime}\right)$ and $6.82\left(2 \mathrm{H}, \mathrm{d}, J=8.4 \mathrm{~Hz}, \mathrm{H}-3^{\prime}, \mathrm{H}-5^{\prime}\right)$ suggested the presence of one 1,2-disubstituted benzene ring and one 1,4-disubstituted benzene ring, respectively. The ${ }^{13} \mathrm{C}-\mathrm{NMR}$ and DEPT data (Table 1 ) revealed the existence of 22 carbon atoms, including $16 \mathrm{sp}^{2}$ carbon atoms, five $\mathrm{sp}^{3}$ methines and one $\mathrm{sp}^{3}$ methylenes, which were attributable to one $p$-coumaroyl moiety, one benzaldehyde moiety and one glucopyranosyl moiety. The above data revealed that the structure of $\mathbf{1}$ was similar to that of $6^{\prime}-\mathrm{O}-(Z)-p$-coumaroylsalicin [21]. Further comparisons of ${ }^{1} \mathrm{H}-\mathrm{NMR},{ }^{13} \mathrm{C}-\mathrm{NMR}$ and DEPT data of 2 with $6^{\prime}-O-(Z)-p$-coumaroylsalicin indicated that there were two major differences between their structures. Firstly, the hydroxymethyl group at C-1 in $6^{\prime}-O-(Z)-p$-coumaroylsalicin was substituted by an aldehyde group in 2, which was supported by the HMBC correlations of H-6 to C-7 $\left(\delta_{C} 191.8\right)$, as well as H-7 to C-1 $\left(\delta_{\mathrm{C}} 127.5\right), \mathrm{C}-2\left(\delta_{\mathrm{C}} 161.3\right)$ and C-6 $\left(\delta_{\mathrm{C}} 128.7\right)$. Secondly, the orientation of the olefinic bond between C- $7^{\prime}$ and C- $8^{\prime}$ was assigned as $E$, based on the typical coupling constant between $\mathrm{H}-7^{\prime}$ and $\mathrm{H}-8^{\prime}$ $(J=16.0 \mathrm{~Hz})$. Detailed analysis of 2D-NMR (HSQC, HMBC and ${ }^{1} \mathrm{H}-{ }^{1} \mathrm{H}$ COSY) spectra confirmed the planar structure of $\mathbf{2}$, as shown in Figure 2. Furthermore, the coupling constant of the anomeric proton resonating at $5.05\left(1 \mathrm{H}, \mathrm{d}, J=7.6 \mathrm{~Hz}, \mathrm{H}-1^{\prime \prime}\right)$ suggested that the glucopyranosyl moiety was $\beta$-glucoside. In order to further confirm the structure of $\mathbf{2}$, the acid hydrolysis reaction of 2 was carried out. As a result, a $\beta$-D-glucose was produced as the sole sugar identified on the basis of the same $R_{f}$ value on co-TLC and the almost identical optical value by comparing with that of an authentic sugar sample. Thus, compound 2 was established as 6-O- $(E)$ - $p$-coumaroyl- $\beta$-D-glucopyranoside-2-benzaldehyde, as shown in Figure 1.

Compound 3 was isolated as a white amorphous powder, possessing the molecular formula of $\mathrm{C}_{21} \mathrm{H}_{22} \mathrm{O}_{9}$ as established by HRESIMS $\left(m / z 441.1158[\mathrm{M}+\mathrm{Na}]^{+}\right.$; calcd. for $\left.\mathrm{C}_{21} \mathrm{H}_{22} \mathrm{O}_{9} \mathrm{Na}, 441.1162\right)$ with an index of hydrogen deficiency of 11. In ${ }^{1} \mathrm{H}-\mathrm{NMR}$ spectrum of 3, two groups of mutual coupled deshielded protons at $\delta_{\mathrm{H}} 7.45(1 \mathrm{H}, \mathrm{d}, J=7.6 \mathrm{~Hz}, \mathrm{H}-5), 7.48(1 \mathrm{H}, \mathrm{dd}, J=7.6,7.6 \mathrm{~Hz}, \mathrm{H}-7), 7.65(1 \mathrm{H}$, $\mathrm{dd}, J=7.6,7.6 \mathrm{~Hz}, \mathrm{H}-6)$ and $7.99(1 \mathrm{H}, \mathrm{d}, J=7.6 \mathrm{~Hz}, \mathrm{H}-8)$, as well as $6.72(1 \mathrm{H}, \mathrm{dd}, J=8.2,2.0 \mathrm{~Hz}$, $\left.\mathrm{H}-6^{\prime}\right), 6.92\left(1 \mathrm{H}, \mathrm{d}, J=2.0 \mathrm{~Hz}, \mathrm{H}-2^{\prime}\right)$ and $7.02\left(1 \mathrm{H}, \mathrm{d}, J=8.2 \mathrm{~Hz}, \mathrm{H}-5^{\prime}\right)$ suggested the presence of one 1,2-disubstituted benzene ring and one 1,2,4-trisubstituted benzene ring, respectively. The ${ }^{13} \mathrm{C}-\mathrm{NMR}$ and DEPT data (Table 2) revealed the presence of 21 carbon atoms, including $13 \mathrm{sp}^{2}$ carbon atoms, six $\mathrm{sp}^{3}$ methines and two $\mathrm{sp}^{3}$ methylenes, which were attributable to one dihydroisocoumarin skeleton and one glucopyranosyl moiety. The above data revealed that the structure of 3 was similar to that of thunberginol G 3'-O-glucoside [22], except that the hydroxyl group at C-8 was substituted by a hydrogen atom, which was supported by the HMBC correlations of H-8 to C-1 $\left(\delta_{\mathrm{C}} 164.9\right), \mathrm{C}-4 \mathrm{a}$ $\left(\delta_{\mathrm{C}} 140.0\right)$ and $\mathrm{C}-8 \mathrm{a}\left(\delta_{\mathrm{C}} 124.8\right)$, as well as the ${ }^{1} \mathrm{H}-{ }^{1} \mathrm{H}$ COSY correlations from $\mathrm{H}-5$ to $\mathrm{H}-8$. Detailed analysis of 2D-NMR (HSQC, HMBC and ${ }^{1} \mathrm{H}-{ }^{1} \mathrm{H}$ COSY) spectra confirmed the planar structure of 3 (see Figure 2). Furthermore, the coupling constant of the anomeric proton resonating at 4.59 $\left(1 \mathrm{H}, \mathrm{d}, J=7.6 \mathrm{~Hz}, \mathrm{H}-1^{\prime \prime}\right)$ suggested that the glucopyranosyl moiety was $\beta$-glucoside. In order to further confirm the structure of $\mathbf{3}$, the acid hydrolysis reaction of $\mathbf{3}$ was carried out. As a result, a $\beta$-D-glucose was produced as the sole sugar identified on the basis of the same $R_{f}$ value on co-TLC and the almost identical optical value by comparing with that of an authentic sugar sample. In addition, the absolute configuration of the aglycone of 3, only holding one chiral center at C-3, was determined as $S$, based on its specific optical rotation of $[\alpha]_{D}^{24}-153.0\left(c 0.9, \mathrm{CH}_{3} \mathrm{OH}\right)$, which was similar with that of (S)-3,4-dihydro-3-phenylisochromen-1-one $\left([\alpha]_{D}^{24}-158.0\right)$, whose structure and absolute configuration had been determined by a combination of spectroscopic analyses and chemical 
methods [23]. Hence, compound 3 was determined as 3S-(4'-hydroxyl-3'-O- $\beta$-D-glucopyranosyl phenyl)-dihydroiso coumarin, as shown in Figure 1.

Table 2. ${ }^{1} \mathrm{H}$ and ${ }^{13} \mathrm{C}-\mathrm{NMR}$ data of compounds 3 and 4 in DMSO- $d_{6}$.

\begin{tabular}{|c|c|c|c|c|}
\hline \multirow{2}{*}{ Position } & \multicolumn{2}{|c|}{ Compound 3} & \multicolumn{2}{|c|}{ Compound 4} \\
\hline & $\delta_{\mathbf{H}^{\mathrm{a}}}$ & $\delta_{\mathrm{C}}^{\mathrm{b}}$ & $\delta_{\mathbf{H}^{\mathrm{a}}}$ & $\delta_{\mathrm{C}}^{\mathbf{b}}$ \\
\hline 1 & & $164.9 \mathrm{~s}$ & & $164.9 \mathrm{~s}$ \\
\hline 2 & & & & \\
\hline 3 & $6.04(1 \mathrm{H}, \mathrm{dd}, 11.6,3.2)$ & $74.2 \mathrm{~d}$ & $5.94(1 \mathrm{H}, \mathrm{dd}, 11.6,3.2)$ & $74.3 \mathrm{~d}$ \\
\hline $4 \alpha$ & $3.27-3.32(1 \mathrm{H}, \mathrm{m})$ & $33.7 \mathrm{t}$ & $3.40-3.43(1 \mathrm{H}, \mathrm{m})$ & $33.2 \mathrm{t}$ \\
\hline $4 \beta$ & $3.12-3.15(1 \mathrm{H}, \mathrm{m})$ & & $3.15-3.17(1 \mathrm{H}, \mathrm{m})$ & \\
\hline $4 a$ & & $140.0 \mathrm{~s}$ & & $140.0 \mathrm{~s}$ \\
\hline 5 & $7.45(1 \mathrm{H}, \mathrm{d}, 7.6)$ & $127.5 \mathrm{~d}$ & $7.39(1 \mathrm{H}, \mathrm{d}, 7.6)$ & $127.5 \mathrm{~d}$ \\
\hline 6 & $7.65(1 \mathrm{H}, \mathrm{dd}, 7.6,7.6)$ & $133.9 \mathrm{~d}$ & $7.64(1 \mathrm{H}, \mathrm{dd}, 7.6,7.6)$ & $133.9 \mathrm{~d}$ \\
\hline 7 & $7.48(1 \mathrm{H}, \mathrm{dd}, 7.6,7.6)$ & $127.8 \mathrm{~d}$ & $7.47(1 \mathrm{H}, \mathrm{dd}, 7.6,7.6)$ & $128.0 \mathrm{~d}$ \\
\hline 8 & $7.99(1 \mathrm{H}, \mathrm{d}, 7.6)$ & $129.3 \mathrm{~d}$ & $7.97(1 \mathrm{H}, \mathrm{d}, 7.6)$ & $129.2 \mathrm{~d}$ \\
\hline $8 a$ & & $124.8 \mathrm{~s}$ & & $124.7 \mathrm{~s}$ \\
\hline $1^{\prime}$ & & $129.9 \mathrm{~s}$ & & $129.3 \mathrm{~s}$ \\
\hline $2^{\prime}$ & $6.92(1 \mathrm{H}, \mathrm{d}, 2.0)$ & $112.8 \mathrm{~d}$ & $6.92(1 \mathrm{H}, \mathrm{d}, 2.0)$ & $112.7 \mathrm{~d}$ \\
\hline $3^{\prime}$ & & $146.9 \mathrm{~s}$ & & $147.1 \mathrm{~s}$ \\
\hline $4^{\prime}$ & & $152.7 \mathrm{~s}$ & & $152.5 \mathrm{~s}$ \\
\hline $5^{\prime}$ & $7.02(1 \mathrm{H}, \mathrm{d}, 8.2)$ & $118.2 \mathrm{~d}$ & $7.09(1 \mathrm{H}, \mathrm{d}, 8.2)$ & $117.6 \mathrm{~d}$ \\
\hline $6^{\prime}$ & $6.72(1 \mathrm{H}, \mathrm{dd}, 8.2,2.0)$ & $115.7 \mathrm{~d}$ & $6.70(1 \mathrm{H}, \mathrm{dd}, 8.2,2.0)$ & $115.5 \mathrm{~d}$ \\
\hline $1^{\prime \prime}$ & $4.59(1 \mathrm{H}, \mathrm{d}, 7.6)$ & $103.5 \mathrm{~d}$ & $4.65(1 \mathrm{H}, \mathrm{d}, 7.6)$ & $102.6 \mathrm{~d}$ \\
\hline $2^{\prime \prime}$ & $3.15-3.13(1 \mathrm{H}, \mathrm{m})$ & $73.3 \mathrm{~d}$ & $3.16-3.14(1 \mathrm{H}, \mathrm{m})$ & $73.4 \mathrm{~d}$ \\
\hline $3^{\prime \prime}$ & $3.22-3.19(1 \mathrm{H}, \mathrm{m})$ & $77.1 \mathrm{~d}$ & $3.23-3.19(1 \mathrm{H}, \mathrm{m})$ & $77.1 \mathrm{~d}$ \\
\hline $4^{\prime \prime}$ & $3.10-3.05(1 \mathrm{H}, \mathrm{m})$ & $69.9 \mathrm{~d}$ & $3.11-3.04(1 \mathrm{H}, \mathrm{m})$ & $69.8 \mathrm{~d}$ \\
\hline $5^{\prime \prime}$ & $3.26-3.23(1 \mathrm{H}, \mathrm{m})$ & $76.3 \mathrm{~d}$ & $3.26-3.24(1 \mathrm{H}, \mathrm{m})$ & $76.6 \mathrm{~d}$ \\
\hline $6^{\prime \prime} \alpha$ & $3.74(1 \mathrm{H}, \mathrm{dd}, 11.6,5.2)$ & $61.0 \mathrm{t}$ & $3.69(1 \mathrm{H}, \mathrm{dd}, 11.6,5.2)$ & $60.8 \mathrm{t}$ \\
\hline $6^{\prime \prime} \beta$ & $3.43(1 \mathrm{H}, \mathrm{dd}, 11.6,6.0)$ & & $3.47(1 \mathrm{H}, \mathrm{dd}, 11.6,6.0)$ & \\
\hline $4^{\prime}-\mathrm{OH}$ & $9.28(1 \mathrm{H}, \mathrm{s})$ & & $9.27(1 \mathrm{H}, \mathrm{s})$ & \\
\hline
\end{tabular}

The molecular formula of 4 was established as $\mathrm{C}_{21} \mathrm{H}_{22} \mathrm{O}_{9}$ by HRESIMS $\left(m / z 441.1161\right.$, $[\mathrm{M}+\mathrm{Na}]^{+}$; calcd. for $\mathrm{C}_{21} \mathrm{H}_{22} \mathrm{O}_{9} \mathrm{Na}, 441.1162$ ), the same with that of 3 . The ${ }^{1} \mathrm{H}$ and ${ }^{13} \mathrm{C}-\mathrm{NMR}$ data (Table 2) of 3 were nearly identical to those of 4 . Detailed analysis of 2D-NMR (HSQC, HMBC and ${ }^{1} \mathrm{H}^{-}{ }^{1} \mathrm{H}$ COSY) spectra confirmed that 4 shared the same planar structure with 3 (see Figure 2). The specific rotation of $4,[\alpha]_{D}^{24}+187.0\left(c 0.10, \mathrm{CH}_{3} \mathrm{OH}\right)$, suggested that its configuration should be different from that of $3\left([\alpha]_{D}^{24}-89.2\right)$. In order to further confirm the structure of 4 , the acid hydrolysis reaction of 4 was carried out. As a result, a $\beta$-D-glucose was produced as the sole sugar identified on the basis of the same $R_{f}$ value on co-TLC and the almost identical optical value by comparing with that of an authentic sugar sample. In addition, the absolute configuration of the aglycone of 4 was determined as $R$, in consideration of its converse optical rotation of $[\alpha]_{D}^{24}+146.0\left(c 0.9, \mathrm{CH}_{3} \mathrm{OH}\right)$ with that of the aglycone of 3, which was very similar with that of $(R)-3,4$-dihydro-3-phenylisochromen-1-one $\left([\alpha]_{D}^{24}+168.5\right)$, whose structure and absolute configuration had been determined by a combination of spectroscopic analyses and chemical methods [24]. Accordingly, compound 4 was identified as the 3-epimer of 3, namely, 3R-(4'-hydroxyl-3'-O- $\beta$-D-glucopyranosylphenyl)-dihydro isocoumarin, as shown in Figure 1.

All new compounds were evaluated for their anti-inflammatory properties via examining the inhibitory activity on NO production induced by LPS in mouse macrophage RAW 264.7 cells in vitro. As a result, new compounds 1 and 4 showed significant inhibitory activities with the $\mathrm{IC}_{50}$ values of $30.23 \pm 1.23 \mu \mathrm{M}$ and $19.36 \pm 0.19 \mu \mathrm{M}$, respectively. While the positive control, L-NMMA (NG-Monomethyl-L-arginine), showed an inhibitory activity with the $\mathrm{IC}_{50}$ value at $32.88 \pm 2.59 \mu \mathrm{M}$. The other compounds showed no inhibitory activity on NO production in this assay $\left(\mathrm{IC}_{50}>100 \mu \mathrm{M}\right)$. No cytotoxicities were observed in compounds 1-4 treated cells (cell viability $>90 \%$ ). 
The above findings may be used as an explanation of the folk use of H. paniculiflorum, which was used as an anti-inflammatory drug in China [1,11]. These findings also suggest that the phenolic glycoside and isocoumarin glycoside with significant inhibitory activities on NO production isolated from $H$. paniculiflorum could be used for the development of new anti-inflammatory agents.

\section{Experimental Section}

\subsection{General Experiment Procedure}

Optical rotations were measured with a JASCO P-1020 digital polarimeter (JASCO Corporation, Tokyo, Japan). UV spectra were recorded on a Beckman DU 640 spectrophotometer (Beckman Instruments, Fullerton, CA, USA). IR spectra were obtained on a Nicolet 6700 spectrophotometer (Thermo Scientific, Madison, WI, USA). NMR spectra were run on a Bruker $400 \mathrm{MHz}$ spectrometer (Bruker Biospin, Rheinstetten, Germany) using TMS as an internal standard. HRESIMS spectra were measured on a Q-TOF Ultima Global GAA076 LC mass spectrometer (Waters Corporation, Milford, MA, USA). Semi-preparative HPLC was performed on an Agilent 1260 LC series (Agilent Technologies, Santa Clara, CA, USA) with a DAD detector using an Agilent Eclipse XDB-C $\mathrm{C}_{18}$ column $(250 \times 9.4 \mathrm{~mm}$, $5 \mu \mathrm{m}$ ). Silica gel (Qing Dao Hai Yang Chemical Group Co., Qingdao, China; 200-300 mesh) and reversed-phase $\mathrm{C}_{18}$ silica gel (YMC; $50 \mu \mathrm{m}$ ) were used for column chromatography (CC). Pre-coated silica gel plates (Yan Tai Zi Fu Chemical Group Co., Yantai, China; G60, F-254) were used for thin layer chromatography (TLC).

\subsection{Plant Material}

The stems of H. paniculiflorum were collected from Bawangling Nature Reserve, Hainan Province China, in August 2012 and identified by Prof. Qiong-Xin Zhong, College of Life Science, Hainan Normal University. A voucher specimen (No. SONG20120818) has been deposited at the Key Laboratory of Tropical Medicinal Plant Chemistry of Ministry of Education, Hainan Normal University.

\subsection{Extraction and Isolation}

The powdered stems of $H$. paniculiflorum $(22.0 \mathrm{~kg})$ were refluxed with methanol for three times. The solvent was evaporated in vacuum to obtain a crude extract. After suspended in water, the crude extract was extracted successively with petroleum ether and EtOAc. The EtOAc extract $(100.0 \mathrm{~g})$ was subjected to silica gel CC, eluted with petroleum ether/EtOAc (from 1:0 to 0:1) yielding five fractions (Fr.1-Fr.5). Fr.4 (16.8 g) was subjected to reversed-phase $\mathrm{C}_{18}$ silica gel CC eluting with $\mathrm{CH}_{3} \mathrm{OH} / \mathrm{H}_{2} \mathrm{O}$ (from $40 \%$ to $100 \%$ ) to afford five fractions (Fr.4A-Fr.4F). Fraction $4 \mathrm{~A}(1.8 \mathrm{~g})$ was purified by Sephadex LH-20 CC eluted with $\mathrm{CH}_{3} \mathrm{OH}$, then separated by a series of silica gel CC eluted with petroleum ether/EtOAc 5:5 to afford $\mathbf{7}(16.3 \mathrm{mg}), \mathbf{1 1}(29.7 \mathrm{mg}), \mathbf{1 2}(23.5 \mathrm{mg})$ and $\mathbf{1 4}(21.3 \mathrm{mg})$. Fraction 4B (2.3 g) was purified by Sephadex $\mathrm{LH}-20 \mathrm{CC}$ eluted with $\mathrm{CH}_{3} \mathrm{OH}$, then separated by a series of silica gel CC eluted with petroleum ether/acetone $6: 4$ to afford $\mathbf{1}(7.8 \mathrm{mg}), \mathbf{2}(9.2 \mathrm{mg})$ and $\mathbf{1 6}(35.8 \mathrm{mg})$. Fraction $4 \mathrm{C}$ $(2.0 \mathrm{~g})$ was purified using Sephadex $\mathrm{LH}-20 \mathrm{CC}$ eluted with $\mathrm{CH}_{3} \mathrm{OH}$, then separated by a silica gel CC eluted with petroleum ether/EtOAc 8:2 to yield $3(8.6 \mathrm{mg}), \mathbf{4}(7.8 \mathrm{mg}), \mathbf{9}(40.2 \mathrm{mg})$ and $17(11.6 \mathrm{mg})$. Fraction $4 \mathrm{~F}(860 \mathrm{mg})$ was purified using Sephadex $\mathrm{LH}-20 \mathrm{CC}$ eluted with $\mathrm{CH}_{3} \mathrm{OH}$, then separated by a semi-preparative HPLC using an Agilent Eclipse XDB- $\mathrm{C}_{18}$ column with $75 \% \mathrm{CH}_{3} \mathrm{OH} / \mathrm{H}_{2} \mathrm{O}$ to afford compound $\mathbf{5}(10.2 \mathrm{mg}), \mathbf{6}(29.0 \mathrm{mg}), \mathbf{8}(22.8 \mathrm{mg}), \mathbf{1 0}(19.6 \mathrm{mg}), \mathbf{1 3}(12.6 \mathrm{mg}), \mathbf{1 5}(15.3 \mathrm{mg})$ and $\mathbf{1 8}(5.3 \mathrm{mg})$.

4-Hydroxy-2-\{[(benzoyl)oxy]methyl\}phenyl- $\beta$-d-glucopyranoside-6-benzoate (1): Colorless amorphous powder; $[\alpha]_{D}^{24}-24.8\left(c 0.12, \mathrm{CH}_{3} \mathrm{OH}\right) ; \mathrm{IR}(\mathrm{KBr}) v_{\max } 3468,2973,1708,1676,1620,1518,1493,1431,1302,1211$ and $1080 \mathrm{~cm}^{-1}$; UV $\left(\mathrm{CH}_{3} \mathrm{OH}\right) \lambda_{\max }(\log \varepsilon) 218(3.03), 262(4.06)$ and $303(1.92) ;{ }^{1} \mathrm{H}$ and ${ }^{13} \mathrm{C}-\mathrm{NMR}$ data (Table 1); ESIMS $m / z 533[\mathrm{M}+\mathrm{Na}]^{+}$; HRESIMS $m / z 533.1413\left([\mathrm{M}+\mathrm{Na}]^{+}\right.$; calcd. for $\mathrm{C}_{27} \mathrm{H}_{26} \mathrm{O}_{10} \mathrm{Na}$, 533.1418). 
6-O-(E)-p-Coumaroyl- $\beta$-d-glucopyranoside-2-benzaldehyde (2): Colorless amorphous powder; $[\alpha]_{D}^{24}+54.2$ (c 0.14, $\left.\mathrm{CH}_{3} \mathrm{OH}\right) ; \mathrm{IR}(\mathrm{KBr}) v_{\max } 3442,1720,1675,1612,1516,1468,1276,1065$ and $704 \mathrm{~cm}^{-1} ; \mathrm{UV}\left(\mathrm{CH} \mathrm{H}_{3} \mathrm{OH}\right)$ $\lambda_{\max }(\log \varepsilon) 222$ (3.76), 272 (4.49) and 308 (1.98) nm; ${ }^{1} \mathrm{H}$ and ${ }^{13} \mathrm{C}-\mathrm{NMR}$ data (Table 1); ESIMS m/z 453 $[\mathrm{M}+\mathrm{Na}]^{+} ; \mathrm{HRESIMS} m / z 453.1163\left([\mathrm{M}+\mathrm{Na}]^{+}\right.$; calcd. for $\left.\mathrm{C}_{22} \mathrm{H}_{22} \mathrm{O}_{9} \mathrm{Na}, 453.1162\right)$.

3S-(4'-Hydroxyl-3'-O- $\beta$-d-glucopyranosylphenyl)-dihydroisocoumarin (3): White amorphous powder; $[\alpha]_{D}^{24}$ -89.2 (c 0.13, $\left.\mathrm{CH}_{3} \mathrm{OH}\right)$; IR (KBr) $v_{\max } 3185,1618,1510,1469,1387,1125$ and $704 \mathrm{~cm}^{-1} ; \mathrm{UV}\left(\mathrm{CH}_{3} \mathrm{OH}\right)$ $\lambda_{\max }(\log \varepsilon) 220$ (4.58), 254 (4.21), 278 (2.56) and 326 (2.19) nm; ${ }^{1} \mathrm{H}$ and ${ }^{13} \mathrm{C}-\mathrm{NMR}$ data (Table 2); ESIMS $m / z 441[\mathrm{M}+\mathrm{Na}]^{+}$; HRESIMS $m / z 441.1158\left([\mathrm{M}+\mathrm{Na}]^{+}\right.$; calcd. for $\left.\mathrm{C}_{21} \mathrm{H}_{22} \mathrm{O}_{9} \mathrm{Na}, 441.1162\right)$.

3R-(4'-Hydroxyl-3'-O- $\beta$-d-glucopyranosylphenyl)-dihydroisocoumarin (4): White amorphous powder; $[\alpha]_{D}^{24}$ +187.0 (c 0.10, $\left.\mathrm{CH}_{3} \mathrm{OH}\right) ; \mathrm{IR}(\mathrm{KBr}) v_{\max } 3188,1616,1516,1472,1388,1127$ and $699 \mathrm{~cm}^{-1} ; \mathrm{UV}\left(\mathrm{CH}_{3} \mathrm{OH}\right)$ $\lambda_{\max }(\log \varepsilon) 223$ (4.62), 258 (4.28), 282 (2.62) and 329 (2.28) nm; ${ }^{1} \mathrm{H}$ and ${ }^{13} \mathrm{C}-\mathrm{NMR}$ data (Table 2); ESIMS $m / z 441[\mathrm{M}+\mathrm{Na}]^{+} ;$HRESIMS $m / z 441.1161\left([\mathrm{M}+\mathrm{Na}]^{+}\right.$; calcd. for $\left.\mathrm{C}_{21} \mathrm{H}_{22} \mathrm{O}_{9} \mathrm{Na}, 441.1162\right)$.

\subsection{Acid Hydrolysis of Compounds 1-4}

Compounds 1-4 (each 1.0-2.0 mg) were refluxed with $2 \mathrm{~mL}$ of $1 \mathrm{~N} \mathrm{HCl}$ for $1 \mathrm{~h}$ at $100{ }^{\circ} \mathrm{C}$. The reaction mixtures were extracted with EtOAc and the aqueous phase was compared to an authentic sugar sample by co-TLC $\left(\mathrm{CHCl}_{3}-\mathrm{CH}_{3} \mathrm{OH}-\mathrm{H}_{2} \mathrm{O}-\mathrm{AcHO}, 13: 3: 3: 1, R_{f} 0.46\right.$ for glucose $)$. The identification of $\beta$-D-glucose in each aqueous layer was realized by comparing the optical rotation of the liberated glucose with that of an authentic sample of $\beta$-D-glucose $\left([\alpha]_{D}^{24}+55.0\right)$.

\subsection{Inhibitory Assay of NO Production}

Murine macrophage cell line RAW264.7 was obtained from Cell Bank of Chinese Academy of Sciences. RAW264.7 cells were seeded in 96-well cell culture plates $\left(1.5 \times 10^{5}\right.$ cells/well $)$ and treated with serial dilutions of the compounds with a maximum concentration of $100 \mu \mathrm{M}$ in triplicate, followed by stimulation with $1 \mu \mathrm{g} / \mathrm{mL}$ LPS (Sigma, St. Louis, MO, USA) for $18 \mathrm{~h}$. NO production in the supernatant was assessed by Griess reagents (Reagent A \& Reagent B, respectively, Sigma). The absorbance at $570 \mathrm{~nm}$ was measured with a microplate reader (Thermo, Waltham, MA, USA). $\mathrm{N}^{\mathrm{G}}$-Methyl-L-arginine acetate salt (L-NMMA, Sigma, Hongkong, China), a well-known nitric oxide synthase (NOS) inhibitor, was used as a positive control [25]. The viability of RAW264.7 cells was evaluated by the MTS assay simultaneously to exclude the interference of the cytotoxicity of the test compounds [26].

\section{Conclusions}

Phytochemical investigation on the stems of $H$. paniculiflorum resulted in the isolation of two new phenolic glycosides (1 and 2) and two new isocoumarin glycosides (3 and 4), along with 14 known compounds (5-18). Their structures were established on the basis of extensive spectroscopic analyses and chemical methods. All new compounds were evaluated for their anti-inflammatory activities via examining the inhibitory activity on NO production induced by LPS in mouse macrophage RAW 264.7 cells in vitro. Compounds 1 and 4 exhibited significant inhibitory activities with $\mathrm{IC}_{50}$ values comparable to that of L-NMMA.

Supplementary Materials: 1D and 2D NMR spectra of compounds 1-4 as Supplementary Materials are available online.

Acknowledgments: This work was financially supported by the National Natural Science Foundation of China (Nos. 21362009, 81360478, 21302181, 21662011 and 31660097), the International S\&T Cooperation Program of China (ISTCP) (2014DFA40850), the Hainan Province Key Research and Development Project (ZDYF2016139) and the Program for Innovative Research Team in University (No. IRT-16R19).

Author Contributions: The list authors contributed to this work as follows: Shou-Yuan Wu, Qi Zhou, Meng Bai, $\mathrm{Si}-\mathrm{Yu}$ Zhao and Guang-Ying Chen performed the isolation, structure elucidation of the chemical constituents and the bioassay experiments; Yan-Hui Fu and Shou-Yuan Wu wrote this manuscript; All the research was performed based on the planning of Xiao-Ping Song and Chang-Ri Han. All authors have read and approved the manuscript. 
Conflicts of Interest: The authors declare no conflict of interest.

\section{References}

1. Fan, G.S. A preliminary study on Flacourtiaceae from China. J. Wuhan Bot. Res. 1990, 8, 131-141.

2. Ekabo, O.A.; Farnsworth, N.R.; Santisuk, T.; Reutrakul, V. A phytochemical investigation of Homalium ceylanicum. J. Nat. Prod. 1993, 56, 699-707. [CrossRef] [PubMed]

3. Ekabo, O.A.; Farnsworth, N.R.; Santisuk, T.; Reutrakul, V. Phenolic, iridoid and ionyl glycosides from Homalium ceylanicum. Phytochemistry 1993, 32, 747-754. [CrossRef]

4. Shaari, K.; Waterman, P.G. Glucosides of 2,5-dihydroxybenzyl alcohol from Homalium longifolium. Phytochemistry 1995, 39, 1415-1421. [CrossRef]

5. Okokon, J.E.; Okokon, P.J.; Dar Farooq, A.; Choudhary, M.I. Anti-inflammatory and antinociceptive activities of Homalium letestui. Pharm. Biol. 2013, 51, 1459-1466. [CrossRef] [PubMed]

6. Shaari, K.; Waterman, P.G. D: A-friedo-oleanane triterpenes from the stem of Homalium longifolium. Phytochemistry 1996, 41, 867-869. [CrossRef]

7. Charubala, R.; Guggisberg, A.; Hesse, M.; Schmid, H. Natural occurrence of 3-phenyl-isocoumarin. Helv. Chim. Acta 1974, 57, 1096-1097. [CrossRef]

8. Govindachari, T.R.; Parthasarathy, P.C.; Desai, H.K.; Ramachandran, K.S. Homalicine and (-)-dihydrohomalicine, two new isocoumarin glucosides from Homalium zeylanicum. Indian J. Chem. 1975, 13, 537-540.

9. Pais, M.; Sarfati, R.; Jarreau, F.X.; Goutarel, R. Homalium alkaloids: Structure of homaline, hopromine, hoprominol and hopromalinol. Tetrahedron 1973, 29, 1001-1010.

10. Wu, S.Y.; Fu, Y.H.; Chen, G.Y.; Li, X.B.; Zhou, Q.; Han, C.R.; Du, X.J.; Xie, M.L.; Yao, G.G. Cytotoxic xanthene derivatives from Homalium paniculiflorum. Phytochem. Lett. 2015, 11, 236-239. [CrossRef]

11. Song, X.P.; Han, C.R.; Yu, J.; Yin, Q.W.; Xu, J.F.; Song, H.W.; Song, X.M. Chemical constituents from the stems of Homalium paniculiflorum. Chin. J. Exp. Tradit. Med. Formulae 2013, 19, 85-88.

12. Ghanadian, M.; Sadraei, H.; Yousuf, S.; Asghari, G.; Choudhary, M.I.; Jahed, M. New diterpene polyester and phenolic compounds from Pycnocycla spinosa Decne. Ex Boiss with relaxant effects on KCl-induced contraction in rat ileum. Phytochem. Lett. 2014, 7, 57-61. [CrossRef]

13. Plourde, G.L.; Fisher, B.B. Synthesis of 6-methoxy-1-oxaspiro [4,5] deca-6,9-diene-8-ne. Molecules 2002, 7, 315-319. [CrossRef]

14. Pettit, G.R.; Melody, N.; Thornhill, A.; Knight, J.C.; Groy, T.L.; Herald, C.L. Antineoplastic agents. 579. Synthesis and cancer cell growth evaluation of E-stilstatin 3: A resveratrol structural modification. J. Nat. Prod. 2009, 72, 1637-1642. [CrossRef] [PubMed]

15. Luo, J.R.; Jiang, H.E.; Zhao, Y.X.; Zhou, J.; Qian, J.F. Components of the heartwood of Populus euphratica from an ancient tomb. Chem. Nat. Compd. 2008, 44, 6-9. [CrossRef]

16. Hacıbekiroğlu, I.; Kolak, U. Antioxidant and anticholinesterase constituents from the petroleum ether and chloroform extracts of Iris suaveolens. Phytother. Res. 2011, 25, 522-529. [CrossRef] [PubMed]

17. Bock, K.; Rein, S. The substrate specificity of amyloglucosidase (AMG). Part IV. Hydroxycyclohexyl glucosides. Acta Chem. Scand. 1989, 43, 373-380. [CrossRef]

18. Kisiel, W.; Barszcz, B. Phenolics from Crepis rhoeadifolia. Fitoterapia 1996, 67, 284-285.

19. Gibbons, S.; Gray, A.I.; Waterman, P.G. Poliothrysins: Novel hydroxycyclohexenone esters from the leaves of Poliothrysis sinensis. Nat. Prod. Lett. 1993, 3, 59-64. [CrossRef]

20. Chai, X.Y.; Xu, Z.R.; Ren, H.Y. Itosides A-I, new phenolic glycosides from Itoa orientalis. Helv. Chim. Acta 2007, 90, 2176-2185. [CrossRef]

21. Kim, C.S.; Subedi, L.; Park, K.J.; Kim, S.Y.; Choi, S.U.; Kim, K.H.; Lee, K.R. Salicin derivatives from Salix glandulosa and their biological activities. Fitoterapia 2015, 106, 147-152. [CrossRef] [PubMed]

22. Yoshikawa, M.; Matsuda, H.; Shimoda, H.; Shimada, H.; Harada, E.; Naitoh, Y.; Miki, A.; Yamahara, J.; Murskami, N. Development of bioactive functions in hydrangeae dulcis folium. V. On the antiallergic and antimicrobial principles of hydrangeae dulcis folium. (2). Thunberginols $C, D$ and E, thunberginol G 3'-O-glucoside, (-)-hydrangenol 4'-O-glucoside and (+)-hydrangenol 4'-O-glucoside. Chem. Pharm. Bull. 1996, 44, 1440-1447. [PubMed] 
23. Kurosaki, Y.; Fukuda, T.; Iwao, M. Asymmetric synthesis of 3-substituted 3,4-dihydroisocoumarins via stereoselective addition of laterally lithiated chiral 2-(O-tolyl) oxazolines to aldehydes followed by diastereomer-selective lactonization. Tetrahedron 2005, 61, 3289-3303. [CrossRef]

24. Chen, J.; Zhou, L.; Tan, C.K.; Yeung, Y.Y. An enantioselective approach toward 3,4-dihydroisocoumarin through the bromocyclization of styrene-type carboxylic acids. J. Org. Chem. 2011, 77, 999-1009. [CrossRef] [PubMed]

25. Reif, D.W.; Mccreedy, S.A. N-nitro-L-arginine and N-monomethyl-L-arginine exhibit a different pattern of inactivation toward the three nitric oxide synthases. Arch. Biochem. Biophys. 1995, 320, 170-176. [CrossRef] [PubMed]

26. Mosmann, T. Rapid colorimetric assay for cellular growth and survival: Application to proliferation and cytotoxicity assays. J. Immunol. Methods 1983, 65, 55-63. [CrossRef]

Sample Availability: Samples of the compounds 1-18 are available from the authors.

(C) 2018 by the authors. Licensee MDPI, Basel, Switzerland. This article is an open access article distributed under the terms and conditions of the Creative Commons Attribution (CC BY) license (http://creativecommons.org/licenses/by/4.0/). 